\title{
FORMATION OF WATER SUPPLY MODULES DURING IRRIGATION OF DRAINED LAND UNDER CLIMATE CHANGE AND LAND RECLAMATION CONDITIONS
}

\author{
Anatoly Rokochynskiy ${ }^{1}$, Yury Mazhayskiy ${ }^{2}$, Pavlo Volk ${ }^{1}$, Vasyl Turcheniuk ${ }^{1}$, \\ Roman Koptyuk $^{1}$, Liubov Volk ${ }^{1}$, Olga Chernikova ${ }^{3}$ \\ ${ }^{1}$ National University of Water and Environmental Engineering, Russia; ${ }^{2}$ All-Russian Research \\ Institute of Hydrotechnics and Melioration named after A.N. Kostyakova, Russia; ${ }^{3}$ Academy of Law \\ Management of the Federal Penal Service of Russia, Russia \\ a.m.rokochinskiy@nuwm.edu.ua, director@mntc.pro,p.p.volk@nuwm.edu.ua, \\ v.o.turchenuk@nuwm.edu.ua, 1.r.volk@ukr.net, chernikova_olga@inbox.ru
}

\begin{abstract}
To justify the calculated water supply module for subsurface irrigation of drained lands, as well as for the drainage flow module, empirical, analytical, water-balance methods are similarly used, or it is determined according to recommendations without sufficient economic and environmental justification, which does not meet modern requirements. Therefore, on the basis of simulation modeling for the conditions of the Ukrainian Polesie, the dynamics, as well as the current and weighted average values of the water supply modules during subsurface humidification in various weather and climatic conditions, including taking into account their possible changes, are established, their significant variability in time and space is established, normalized curves of the water supply module security for the main cultivated crops (cereals, potatoes, grasses) on mineral and peat soils are constructed. It is established that both the current and average values of the water supply module under the studied conditions, similar to the drainage flow module, have a pronounced variable character in climatic conditions, the type of crops grown and the type of soil. Its value, both for the identified main factors and for the system as a whole operating in the subsurface humidification mode, differs significantly (more than several times), first of all, both from their maximum current 2.0-3.0 $1 \cdot \mathrm{s}^{-1} \cdot$ ha, and from the average vegetation values of $0.39-0.961 \cdot \mathrm{s}^{-1} \cdot \mathrm{ha}$, which significantly differs from their recommended calculated values. At the same time, the water demand of cultivated crops increases almost two to three times. This makes it necessary to take into account this variation of this indicator by improving existing methods and approaches to substantiating the calculated value of the water supply module, when developing projects for the reconstruction, modernization, construction and operation of such facilities.
\end{abstract}

Keywords: water supply module, humidification, drained lands, climate change, agromeliorative conditions.

\section{Introduction}

Today the existing complex irrigation systems (CIS), primarily in the Polesie zone, have exhausted their resource potential and need reconstruction and modernization to improve the overall technological, economic and environmental efficiency of their functioning, including in terms of climate change [1-3].

The predicted increase in the air temperature and increased aridity under climate change, which are already observed today, will inevitably lead to a decrease in the natural moisture supply of the territory, an increase in potential evaporation and, accordingly, the total water demand when growing crops on drained lands. In turn, the lack of natural moisture requires additional moistening of cultivated crops through the implementation of appropriate water regulation technologies to moisten the drained lands.

Therefore, the issue of changing approaches and developing a number of new measures to adapt to climate change in the design and reconstruction of water management and reclamation facilities becomes extremely urgent. First of all, it is necessary to improve the technologies and regimes of water regulation on drained lands, to transfer them instead of periodic to regular moistening, as well as regulation and accumulation of water in the soil profile and within the system as a whole [4-9].

This determines the need to revise the existing requirements for the justification of operational, technological and structural solutions in the design and construction of the CIS, taking into account the above changes.

One of the most important technological parameters of the CIS during the operation of the collectordrainage system in the mode of subsurface irrigation is the water supply module, as well as the drainage flow module during drainage. These indicators and their parameters quantitatively and qualitatively reflect the efficiency of regulation of the water regime of drained soil in periods of different moisture content along their profile and throughout the drained area as a whole [4].

In this regard, the purpose of the research is to study the conditions for the formation, determination and substantiation of water supply modules, when carrying out subsurface irrigation on drained lands in 
climate change and agromeliorative conditions, which decisively affect the water regime of soil and territories in the service area of CIS.

\section{Materials and methods}

As for the drainage flow module [4], empirical, analytical, water-balance methods and models traditionally used in domestic and foreign practice were analyzed and generalized to substantiate the calculated values of the water supply module with subsurface irrigation of drained lands.

Investigations into the formation of water supply modules during moistening of drained lands in climate change and agromeliorative conditions are based on the use of an appropriate complex of forecasting and simulation models. They include a model of the local climate, a model of the water regime and technologies for water regulation of drained lands, a model of the development and formation of the yield of cultivated crops and are implemented on the basis of a long-term forecast. Their practical application is regulated by the relevant industry standards of the State Water Agency of Ukraine [10-11].

On their basis, for the conditions of Ukrainian Polesie, the dynamics and changeable nature of the current average decadal and average weighted values of the water supply modules were established, when carrying out subsurface irrigation for the main crops, mineral and peat soil, calculated according to the conditions of heat and moisture supply during the growing season in current weather and climatic conditions and in conditions, taking into account their possible changes, as well as in the whole system.

Based on the results of assessing their significant variability in time and space, normalized curves of the provision of the water supply module were plotted for the main crops grown on mineral and peat soil.

The main methods of the general theory of the experiment were also used: analytical, experimental and statistical; mathematical modeling and machine experiment using modern information and computer technologies. The processing of the results of field research and simulation data was carried out using the methods of mathematical statistics, probability theory and correlation analysis.

\section{Results and discussion}

When studying the issue of substantiating the calculated values of the water supply module, an analysis of domestic and foreign methods and models for its determination was carried out.

So, in due time for the conditions of Ukraine A.M. Yangol [12] recommended to determine the calculated moisture modules depending on the distance between the $E$ drains and the specific water flow from the moistening $q_{3}$ drains according to the following formula

$$
q_{3}=\frac{2 k a}{E}\left\{h_{0}^{2}-\left[\frac{h_{1} h_{2} T_{p}}{h_{2} T_{p}-\left(h_{2}-h_{1}\right) T}\right]^{2}\right\},
$$

where $\quad k$ - filtration coefficient, $\mathrm{m} \cdot$ day $^{-1}$;

$T_{p}$ - specified duration of humidification, $\left(0<T<T_{p}\right)$, days;

$h_{0}$ - given depth of water in the canal or above the drain during the period of humidification, counting from the bottom, $\mathrm{m}$;

$h_{1}, h_{2}$ - initial (before humidification) and given GWL in the middle between humidifiers, counting from the bottom of the humidifier, $\mathrm{m}$;

$a$ - coefficient determined by the following formula

$$
a=1+2.2 \sqrt{\frac{H_{0}-t}{H_{0}} \cdot \frac{2 h_{0} \pi}{t}},
$$

where $H_{0}$ - depth of the aquiclude from the surface, $\mathrm{m}$;

$h_{0}$ - depth of the water in the humidifier (when the bottom lies on the aquiclude; $H_{0}=$ t; $a=1)$;

$\beta$ - active soil difference in unit fractions. 
Then the module of subsurface irrigation $q_{h}$ is proportional to the intensity of water outflow from the drain and the density of the drainage system $\xi$

$$
q_{h}=q_{3} \cdot \xi .
$$

For approximate calculations, it is recommended to take the following values of $q_{h}$ for:

- $\quad$ sands and sandy loams $8.0 \ldots 6.01 \cdot \mathrm{s}^{-1} \cdot \mathrm{ha}$;

- medium loams and peats $4.0 \ldots 6.01 \cdot \mathrm{s}^{-1} \cdot$ ha;

- heavy cultivated loams 3.0...5.0 $1 \cdot \mathrm{s}^{-1} \cdot$ ha;

According to the research by Radchenko I. [13], the inflow of water from the drain into the ground is determined by the following formula

$$
q=115.74 \frac{h_{0} k}{E} \cdot \frac{a \beta \gamma}{B}\left(\frac{k \cdot T}{\mu \cdot B \cdot E}\right)^{\beta-1} \exp \left[-a\left(\frac{k \cdot T}{\mu \cdot B \cdot E}\right)^{\beta}\right],
$$

where $h_{0}$ - piezometric height of the water level in the drains;

$\mu$ - coefficient of lack of soil saturation;

$T$ - time from the beginning of the infiltration process under pressure;

$a$ and $\beta$-parameters that depend on the ratio of $D / E$ and $h_{0} / E$;

$E$ - depth of the aquiclude;

$B$ - parameter characterizing the influence of the active perimeter of regulating drains $\left(l_{d}=\pi d\right)$ with an increase in GWL.

Accordingly, the maximum inflow is determined by the following formula

$$
q_{m}=115.74 \frac{k h_{0}}{E} \cdot \frac{a \beta \gamma}{B}\left[\frac{1}{a}\left(1-\frac{1}{\beta}\right)\right]^{1-\frac{1}{\beta}} \exp \left[-\left(1-\frac{1}{\beta}\right)\right] .
$$

According to the research of Turbin V.N. [14], the approximate humidification module is calculated from the amount of water outflow from the humidifier

$$
q_{0}=\frac{K}{L}\left(h_{0}^{2}-h^{2}\right),
$$

where $q_{0}-$ outflow of water from supported humidifier drain per unit length on one side $\mathrm{m}^{3} \cdot \mathrm{s}^{-1}$;

$K$ - filtration coefficient, $\mathrm{m} \cdot$ day $^{-1}$;

$L-1 / 2$ distances between drains-humidifiers, $\mathrm{m}$;

$h_{0}$ - height of the backwater in the drain, counting from its bottom, m;

$h$ - height of the groundwater level in the middle between the humidifier drains, counting from the bottom of the drain, $m$.

Formula (6) is valid, when the drain is located on the aquiclude. When the aquiclude is located below the bottom of the drain, a hanging coefficient is introduced.

Then the formula takes the form

$$
q_{0}=\frac{K}{L}\left(h_{0}^{2}-h^{2}\right) \cdot B,
$$

where the designations are the same as in formula (6).

On sod-alluvial medium loams with a filtration coefficient $k_{f}=1.28 \mathrm{~m} \cdot$ day $^{-1}$ at a depth of $60 \mathrm{~cm}$, for 4 years humidification modules averaged $6.0 \ldots 4.01 \cdot \mathrm{s}^{-1} \cdot$ ha at a distance of $10-15 \mathrm{~m}$ between drains and, accordingly, $4.0 \ldots 3.01 \cdot \mathrm{s}^{-1} \cdot$ ha - at a distance of $20-30 \mathrm{~m}$ between drains.

According to the experimental data of V.M. Labrencis [15], the outflow of water and, therefore, the module of humidification strongly depends on the diameter of the drain (Table 1). At the same time, the influence of the diameter is much greater than it follows from the theoretical dependences.

Table 1 
Average values of humidification modules $\left(l \cdot \mathrm{s}^{-1} \mathrm{ha}\right)$ depending on diameter $(d)$, distance between drains $(E)$ and slope $(i)$

\begin{tabular}{|c|c|c|c|c|c|c|}
\hline \multirow{2}{*}{$\boldsymbol{i}, \boldsymbol{\%}$} & \multicolumn{3}{|c|}{$\boldsymbol{d = 5 0 ~ \mathbf { ~ m m }}$} & \multicolumn{3}{c|}{$\boldsymbol{d = 7 0 ~ \mathbf { ~ m m }}$} \\
\cline { 2 - 7 } & $E=20 \mathrm{~m}$ & $E=16 \mathrm{~m}$ & $E=12 \mathrm{~m}$ & $E=20 \mathrm{~m}$ & $E=16 \mathrm{~m}$ & $E=12 \mathrm{~m}$ \\
\hline 0.8 & 2.5 & 3.0 & 3.6 & 7.5 & 9.0 & 10.9 \\
\hline 0.6 & 2.0 & 2.4 & 2.9 & 6.5 & 7.8 & 9.5 \\
\hline 0.4 & 1.5 & 1.8 & 2.2 & 5.5 & 6.6 & 7.9 \\
\hline 0.2 & 1.0 & 1.2 & 1.5 & 4.0 & 4.2 & 5.8 \\
\hline
\end{tabular}

According to the results of scientific and industrial research of various methods of water regulation, carried out by us in the zones of Polesie and forest-steppe of Ukraine, according to [11], technologies of water regulation during preventive and humidifying sluicing, the use of sprinkling irrigation on drained lands, elements of technology and humidification regime, methods of their calculation were developed and recommended for production for implementation.

Comparative characteristics of the main elements of irrigation techniques and components of various modes of subsurface irrigation of drained lands during dry growing seasons are presented in Table 2 .

Table 2

\section{Comparative characteristics of main elements of irrigation technique for drained lands under different modes of subsurface irrigation}

\begin{tabular}{|c|c|c|c|c|}
\hline \multirow{2}{*}{ Characteristics } & \multicolumn{4}{|c|}{ Option } \\
\hline & \multicolumn{2}{|c|}{1} & \multicolumn{2}{|c|}{2} \\
\hline Moistening method & \multicolumn{2}{|c|}{$\begin{array}{l}\text { Subsoil moistening with } \\
\text { long-term backwatering of } \\
\text { water levels }\end{array}$} & \multicolumn{2}{|c|}{$\begin{array}{l}\text { Subsoil moistening by } \\
\text { cyclical changes in GWL }\end{array}$} \\
\hline Type of soil & min. & peat. & $\min$. & peat \\
\hline Irrigation rates net, $\mathrm{m}^{3} \cdot \mathrm{ha}^{-1}$ & $200 \ldots 900$ & $300 \ldots 800$ & $400 \ldots 800$ & - \\
\hline Duration of irrigation, days & \multicolumn{2}{|c|}{$7 . .20$} & \multicolumn{2}{|c|}{$12 . .17$} \\
\hline Number of irrigations & \multicolumn{2}{|c|}{$1 \ldots 3$} & \multirow{2}{*}{\multicolumn{2}{|c|}{$\frac{2 \ldots 4}{0 . .412}$}} \\
\hline Water supply module, $1 \cdot \mathrm{s}^{-1} \cdot$ ha & \multicolumn{2}{|c|}{$0.2 \ldots 0.6$} & & $0.7 \ldots 1.2$ \\
\hline Irrigation rates gross, $\mathrm{m}^{3} \cdot \mathrm{ha}^{-1}$ & $800 \ldots 2400$ & $600 \ldots 1800$ & $1200 \ldots 2800$ & - \\
\hline Required head in the control network, $\mathrm{m}$ & \multicolumn{2}{|c|}{$0.5 \ldots 0.2$} & \multicolumn{2}{|c|}{$1.0 \ldots 0.8$} \\
\hline Efficiency factor of method & \multicolumn{2}{|c|}{$0.6 \ldots 0.8$} & \multicolumn{2}{|c|}{$0.5 \ldots 0.7$} \\
\hline
\end{tabular}

Note. For cyclic moistening, in contrast to other methods, the phase of the rise in GWL lasts 7-10 days, the phase of decrease in the GWL 3-7 days. levels.

In practice, the most common method is subsurface irrigation with long-term backwatering of water

Thus, according to the generalized results of the research carried out for Polesie and forest-steppe zones of Ukraine, when calculating the drainage parameters, the values of the water supply modules were taken within:

- for mineral soil 8.0...6.0 $\mathrm{l} \cdot \mathrm{s}^{-1} \cdot \mathrm{ha}$;

- for peat soil $4.0 \ldots 6.01 \cdot \mathrm{s}^{-1} \cdot \mathrm{ha}$.

In turn, these recommended values, as calculated ones, did not justify themselves from the point of view that the drainage parameters established for them to take into account, in general, only the technological conditions of operation. But at the same time, they do not sufficiently take into account the technology of humidification, the types of crops grown, the variability of weather and climatic conditions, as well as the conditions for the formation of an economic and absolutely ecological effect, that is, they are not economically and ecologically optimal for calculating the CIS as a whole [3; 4].

Therefore, there is an objective need to consider not only drainage, but also climate change, hydrogeological, agrotechnical, economic and environmental conditions, as well as the types, values, productivity and profitability of grown crops [4]. 
In this regard, it is of interest to study changes in the conditions for the formation of water supply modules and their parameters, when moistening drained lands in changeable natural-agro-reclamation conditions of a real object in order to clarify their calculated values, when developing projects for reconstruction and new construction of CIS.

To accomplish this task, we planned and carried out a large-scale machine experiment using modern information and computer technologies. The research is based on the use of an appropriate set of forecasting and simulation models, which include a terrain climate model, a model of the water regime and technologies for water regulation of drained lands, a model of the development and formation of the yield of cultivated crops, and are implemented on the basis of a long-term forecast [4,10, 11 etc.].

The object of research is the "Birki" polder drainage system in the Rivne region of Ukraine. On this system, both mineral soil and peat soil are represented, and according to its design, it is possible to implement almost all the main technologies for water regulation of drained lands. The gross area of the system is $\mathbf{5 4 4 . 9}$ hectares, pottery drainage is laid on an area of 444 hectares, bilateral regulation is possible on an area of 177.9 hectares, the area of a polder with mechanical drainage is 470 hectares. The Styr river serves as the water intake for the system. During dry periods, the water from the system is not pumped out, but is used for humidification measures.

Predictive calculations in simulation modeling are performed for the following multiple variable conditions:

- the main meteorological characteristics: precipitation, temperature, relative humidity and lack of air humidity;

- for five groups calculated according to the conditions of heat and moisture supply of the growing season: very wet $-p=10 \%$; wet $-p=30 \%$; medium $-p=50 \%$; dry $-p=70 \%$; very dry $-p=90 \%$;

- soil: soddy-gley sandy loam with a filtration coefficient $\left(k_{f}=1.0 \mathrm{~m} \cdot\right.$ day $\left.^{-1}\right)$ and share participation in the system $\left(f_{g m}=0.4\right)$, and medium-thick, medium-decomposed peatlands $\left(k_{f}=0.4 \mathrm{~m} \cdot\right.$ day $\left.^{-1}, f_{g m}=0.6\right)$;

- the main grown crops: winter wheat, potatoes, perennial grasses;

- by levels and corresponding periods for assessing the implementation of weather and climatic conditions:

- $\quad$ recent - (1991-2015);

- forecast - according to the climate model UKMO - the model of the United Kingdom Met Office, provides for an increase in the average annual air temperature by $6^{\circ} \mathrm{C}$, when the $\mathrm{CO}_{2}$ content doubles in the atmosphere. This model, in forecast operating calculations, takes into account more critical scenarios of changes in weather and climatic conditions and is better consistent with the models that we used for the predictive assessment of normalized distribution of the main meteorological characteristics in the long-term and intra-growing section [2].

The generalized results of the established vegetation values of the main meteorological characteristics for the periods of their assessment and calculated years for the conditions of Western Polesie of Ukraine are given in Table 3.

Table 3

Vegetation values of main meteorological characteristics by periods of their assessment and calculated years for conditions of Western Polesie of Ukraine

\begin{tabular}{|c|c|c|c|c|c|c|}
\hline \multicolumn{2}{|c|}{ Indicators, conditions } & \multicolumn{4}{|c|}{ Years of estimated supply, \% } \\
\cline { 3 - 6 } & $\mathbf{1 0 \%}$ & $\mathbf{3 0 \%}$ & $\mathbf{5 0 \%}$ & $\mathbf{7 0 \%}$ & $\mathbf{9 0 \%}$ \\
\hline \multirow{2}{*}{ Amount of precipitation $(P, \mathrm{~mm})$} & Recent conditions & 575.1 & 5091.0 & 443.0 & 377.0 & 310.9 \\
\cline { 2 - 6 } & Forecast conditions & 615.64 & 545.71 & 475.77 & 405.83 & 335.89 \\
\hline \multirow{2}{*}{ Average temperature air $(T, \mathrm{C})$} & Recent conditions & 12.7 & 13.1 & 13.5 & 13.7 & 14.2 \\
\cline { 2 - 6 } & Forecast conditions & 17.26 & 17.69 & 18.16 & $18, .39$ & 18.98 \\
\hline \multirow{2}{*}{ Amount of air humidity deficit $(D, \mathrm{~mm})$} & Recent conditions & 698 & 785 & 849 & 943 & 1036 \\
\cline { 2 - 6 } & Forecast conditions & 893.0 & 1005.0 & 1078.0 & 1207.0 & 1295.0 \\
\hline \multirow{2}{*}{ Average relative air humidity $(H, \%)$} & Recent conditions & 80.6 & 77.7 & 75.3 & 72.1 & 69.4 \\
\cline { 2 - 6 } & Forecast conditions & 73.36 & 71.73 & 68.46 & 65.77 & 63.42 \\
\hline
\end{tabular}


On the basis of predictive and simulation modeling, the average ten-day values and the variable nature of the values of the water supply modules were established, they are formed on the system, when carrying out subsurface irrigation with prolonged back-up of levels for crops, soil and calculated years in the conditions of Western Polesie of Ukraine (Fig. 1).

a)

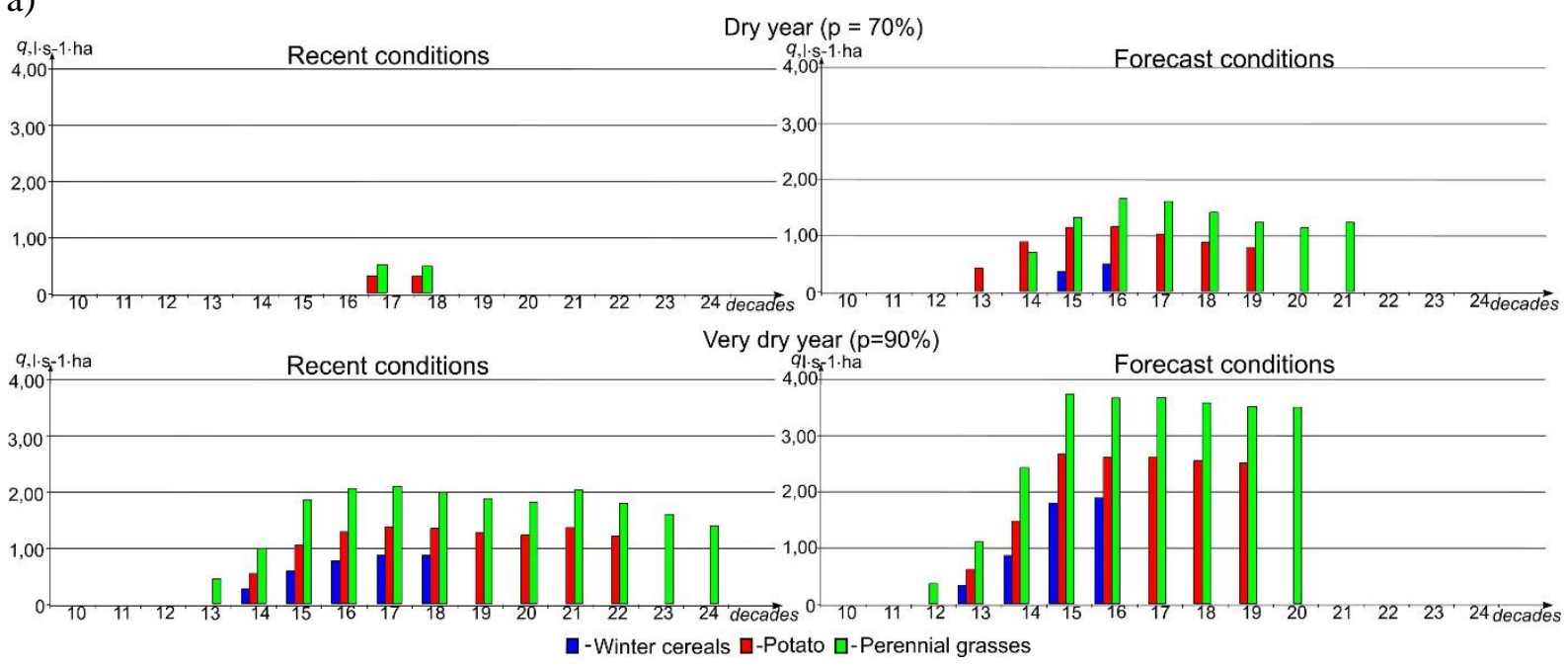

b)
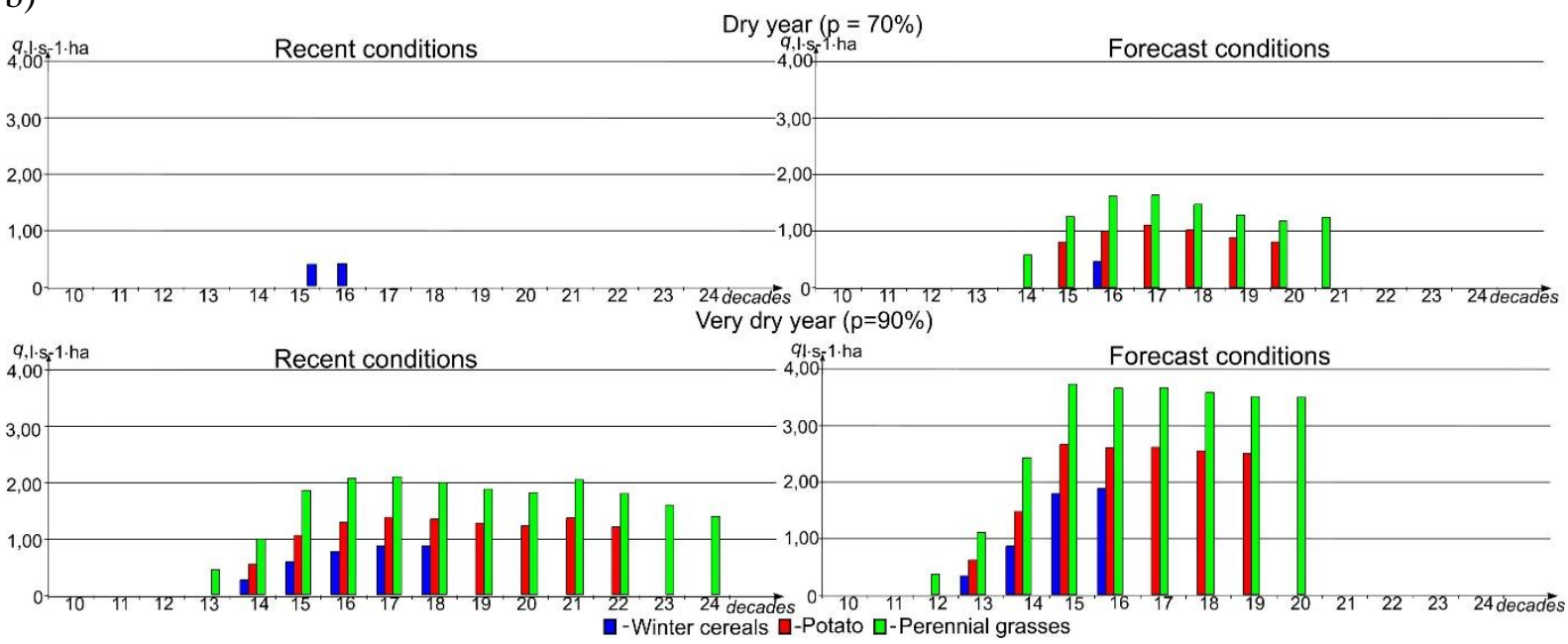

Fig. 1. Dynamics of average ten-day values of water supply modules during subsurface irrigation of main crops on: $a$ - mineral and $b$ - peat soil in climate change conditions

of Western Polesie zone of Ukraine

The above results show (see Fig. 1) that under different climatic conditions, including taking into account their possible changes, when growing different crops on different soil, there is a significant change in the values of the water supply modules with subsurface irrigation.

During the growing season, the values of water supply modules under recent climatic conditions for cereals, perennial grasses and potatoes on mineral soil are $0.2 \ldots 0.551 \cdot \mathrm{s}^{-1} \cdot \mathrm{ha}$ in a dry year, $0.6 \ldots 2.01 \cdot \mathrm{s}^{-1} \cdot$ ha in a very dry year, and on peat soil $-0.1 \ldots 0.45 \mathrm{l} \cdot \mathrm{s}^{-1} \cdot \mathrm{ha} ; 0.4 \ldots 1.8 \mathrm{l} \cdot \mathrm{s}^{-1} \cdot$ ha. For forecast climatic conditions, taking into account changes, on mineral soil, their values are $0.5 \ldots 1.651 \cdot \mathrm{s}^{-1} \cdot$ ha in a dry year, in a very dry year $-1.5 \ldots 2.81 \cdot \mathrm{s}^{-1} \cdot \mathrm{ha}$, and on peat soil $-0.4 \ldots 1.451 \cdot \mathrm{s}^{-1} \cdot \mathrm{ha}$ and $1.6 \ldots 3.01 \cdot \mathrm{s}^{-1} \cdot$ ha, respectively.

The generalized results on the variability and the formation of ten-day average values of water supply modules during subsurface irrigation within the system for the conditions under consideration are presented in Table 4.

The above results indicate that both the current and the averaged values of the water supply module under the researched conditions, similar to the drainage flow module [4], have a pronounced changeable character in climatic conditions, the type of grown crops and the type of soil. At the same time, its value, 
both for the identified main factors and for the system as a whole, operating in the mode of subsurface irrigation, significantly (more than several times) differs, first of all, from both their maximum current and average growing values.

It should also be noted that in the predicted changing climatic conditions, the water demand of crops grown on drained lands also increases significantly (almost two to three times).

Based on the results obtained on the study of the conditions for the formation of water supply modules under subsurface irrigation in climate change and land reclamation conditions, the corresponding supply curves were constructed according to their averaged maximum values during the growing season of the main cultivated crops on drained mineral and peat soil (Fig. 2).

Table 4

Generalized results on variability and formation of ten-day average values of water supply modules during subsurface irrigation within the system for conditions of Western Polesie of Ukraine

\begin{tabular}{|c|c|c|c|c|c|c|c|}
\hline \multirow[b]{3}{*}{ Crops } & \multirow{3}{*}{$\begin{array}{l}\text { Proporti } \\
\text { on of } \\
\text { crop in } \\
\text { crop } \\
\text { rotation }\end{array}$} & \multicolumn{6}{|c|}{ Calculated water supply modules, $1 \cdot \mathrm{s}^{-1} \cdot \mathrm{ha}$} \\
\hline & & \multicolumn{3}{|c|}{ Recent conditions } & \multicolumn{3}{|c|}{$\begin{array}{l}\text { Forecast conditions } \\
\end{array}$} \\
\hline & & $p=70 \%$ & $p=90 \%$ & $\begin{array}{c}\text { Average } \\
\text { weighted } \\
\text { values }\end{array}$ & $p=70 \%$ & $p=90 \%$ & $\begin{array}{c}\text { Average } \\
\text { weighted } \\
\text { values }\end{array}$ \\
\hline \multicolumn{8}{|c|}{ Mineral soil } \\
\hline $\begin{array}{l}\text { Winter } \\
\text { cereals }\end{array}$ & 0.2 & $\frac{0.00-0.00}{0.00}$ & $\frac{0.86-0.25}{0.17}$ & $\frac{0.12-0.04}{0.02}$ & $\frac{0.49-0.00}{0.12}$ & $\frac{1.79-0.27}{0.69}$ & $\frac{0.39-0.04}{0.13}$ \\
\hline Potatoes & 0.3 & $\frac{0.32-0.02}{0.06}$ & $\frac{1.35-0.53}{1.06}$ & $\frac{0.28-0.08}{0.17}$ & $\frac{1.16-0.72}{0.70}$ & $\frac{2.66-0.52}{1.67}$ & $\frac{0.68-0.26}{0.42}$ \\
\hline $\begin{array}{c}\text { Perennial } \\
\text { grasses }\end{array}$ & 0.5 & $\frac{0.54-0.02}{0.06}$ & $\frac{2.08-0.44}{1.32}$ & $\frac{0.44-0.07}{0.21}$ & $\frac{1.66-0.51}{0.86}$ & $\frac{3.67-0.91}{2.13}$ & $\frac{0.96-0.26}{0.53}$ \\
\hline $\begin{array}{l}\text { For the } \\
\text { system as } \\
\text { a whole }\end{array}$ & 1.0 & $\frac{0.33-0.01}{0.04}$ & $\frac{1.48-0.37}{0.90}$ & $\frac{0.30-0.05}{0.14}$ & $\frac{1.16-0.49}{0.59}$ & $\frac{2.72-0.36}{1.53}$ & $\frac{0.69-0.17}{0.37}$ \\
\hline \multicolumn{8}{|c|}{ Peat soil } \\
\hline $\begin{array}{l}\text { Winter } \\
\text { cereals }\end{array}$ & 0.2 & $\frac{0.00-0.00}{0.00}$ & $\frac{0.86-0.25}{0.30}$ & $\frac{0.13-0.03}{0.05}$ & $\frac{0.41-0.6}{0.06}$ & $\frac{1.75-0.32}{0.60}$ & $\frac{0.37-0.13}{0.10}$ \\
\hline Potatoes & 0.3 & $\frac{0.00-0.00}{0.00}$ & $\frac{1.35-0.53}{0.97}$ & $\frac{0.20-0.07}{0.14}$ & $\frac{0.97-0.41}{0.55}$ & $\frac{2.73-0.61}{1.62}$ & $\frac{0.65-0.19}{0.38}$ \\
\hline $\begin{array}{c}\text { Perennial } \\
\text { grasses }\end{array}$ & 0.5 & $\frac{0.46-0.02}{0.05}$ & $\frac{2.08-0.44}{1.04}$ & $\frac{0.43-0.06}{0.17}$ & $\frac{1.44-0.69}{0.76}$ & $\frac{3.95-0.36}{2.51}$ & $\frac{0.95-0.22}{0.57}$ \\
\hline $\begin{array}{l}\text { For the } \\
\text { system as } \\
\text { a whole }\end{array}$ & 1.0 & $\frac{0.23-0.01}{0.03}$ & $\frac{1.62-0.37}{0.87}$ & $\frac{0.30-0.05}{0.14}$ & $\frac{1.09-0.54}{0.56}$ & $\frac{3.14-0.48}{1.86}$ & $\frac{0.74-0.38}{0.42}$ \\
\hline
\end{tabular}

Note:

$\underline{0.23-0.26}$ - maximum and minimum values of water supply modules.

0.03 - average values of water supply modules

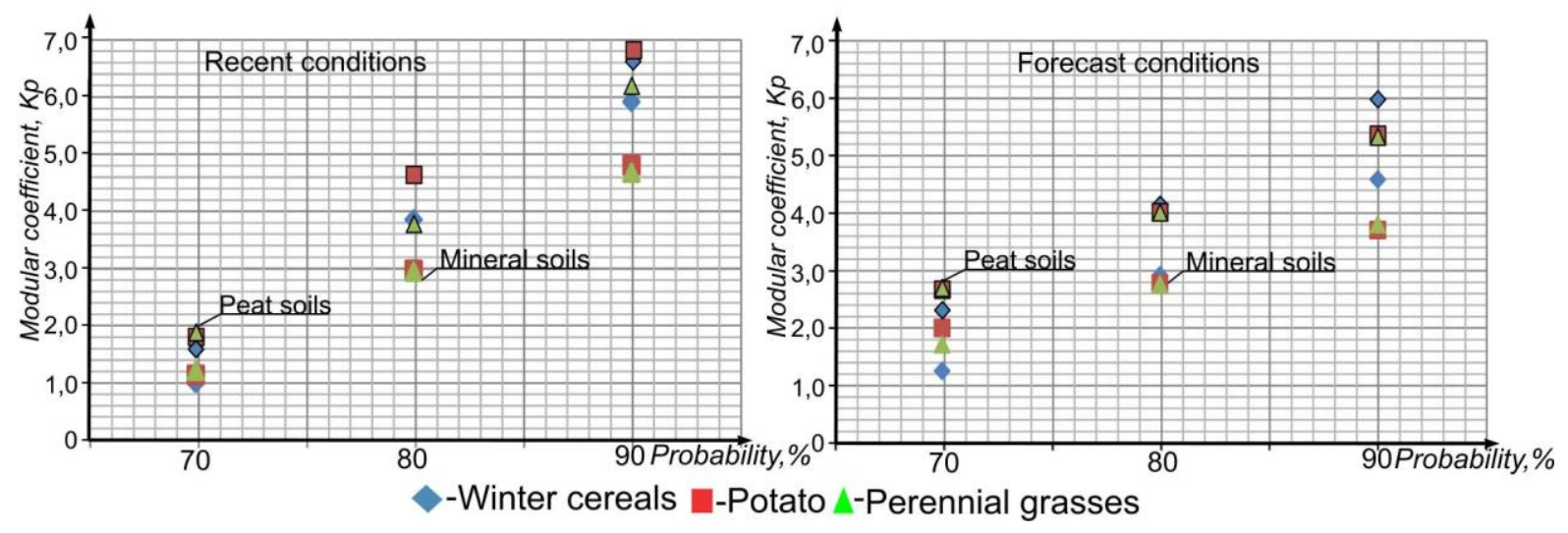

Fig. 2. Curves of provision of water supply with subsurface irrigation for main agricultural crops grown on drained mineral and peat soil in conditions of Western Polesie of Ukraine 
It was found that the binomial Pearson curves of I type are most suitable as distribution curves under the studied conditions

$$
y=y_{0}\left(1+\frac{x}{a}\right)^{m_{1}} \cdot\left(1+\frac{x}{a_{2}}\right)^{m_{2}},
$$

where $a, a_{2}$ and $m_{1}, m_{2}$ coefficients of the I type Pearson curve were determined by the least squares method and are presented in Table 5.

Table 5

\section{Characteristic of $a, a_{2}$ variation, and $m_{1}, m_{2}$ asymmetry for maximum valuesof water supply modules}

\begin{tabular}{|c|c|c|c|c|c|c|c|}
\hline \multicolumn{8}{|c|}{ Coefficients of variation and asymmetry } \\
\hline \multicolumn{7}{|c|}{ Recent conditions } & \multicolumn{5}{c|}{ Forecast conditions } \\
\hline$\underline{2.13}$ & $a_{2}$ & $m_{1}$ & $m_{2}$ & $a$ & $a_{2}$ & $m_{1}$ & $m_{2}$ \\
\hline 3.48 & $\underline{2.25}$ & $\underline{2.99}$ & $\underline{1.20}$ & $\underline{1.33}$ & $\underline{1.45}$ & $\underline{2.37}$ & $\underline{1.28}$ \\
\hline
\end{tabular}

Note. $\quad 2.13$ - coefficients of variation and asymmetry for mineral soil

3.48 - coefficients of variation and asymmetry for peat soil

The obtained results indicate that the distribution law of the water supply module with subsurface irrigation is generally similar in nature, but opposite in the direction of change to the distribution law of the drainage flow module [4] and corresponds to the nature of changes in the previously established patterns of distribution of the main climatic characteristics (precipitation, temperature, deficit of relative air humidity) in the studied conditions and confirms the determining dependence of their formation on climatic factors.

\section{Conclusions}

1. As a result of the conducted studies, it was found that both the current and average values of the water supply module for subsurface irrigation of drained lands, similar to the drainage runoff module, have a pronounced variability in climatic conditions (from $0.551 \cdot \mathrm{s}^{-1} \cdot$ ha in a dry year to $2.01 \cdot \mathrm{s}^{-1} \cdot$ ha in a very dry year), the type of crops grown (from $0.17 \mathrm{l} \cdot \mathrm{s}^{-1} \cdot \mathrm{ha}$ for cereals to $1.32 \mathrm{l} \cdot \mathrm{s}^{-1} \cdot$ ha for grasses), the type of soil (from $1.531 \cdot \mathrm{s}^{-1} \cdot$ ha for mineral resources up to $1.86 \mathrm{l} \cdot \mathrm{s}^{-1} \cdot$ ha on peat in climate change conditions).

2. At the same time, its value, both for the selected main factors and for the system as a whole, differs significantly (more than several times), first of all, both from their maximum current 2.0-3.0 $1 \cdot \mathrm{s}^{-1} \cdot \mathrm{ha}$, and the average vegetation values from $0.39-0.961 \cdot \mathrm{s}^{-1} \cdot \mathrm{ha}$, which significantly differs from their recommended calculated values. The water demand of cultivated crops increases almost two to three times.

3. The results obtained make it necessary to take into account this variation of this indicator by improving existing methods and approaches to substantiating the calculated value of the water supply module in the development of projects for the reconstruction, modernization, construction and operation of drainage systems with subsurface moisture.

\section{References}

[1] About approval of the Concept for the implementation of state policy in the field of climate change until 2030: Order of the Cabinet of Ministers No. 932-r of December 7, 2016 [online] [29.04.2020] Available at: https://www.kmu.gov.ua/ua/npas/249573705 (In Ukrainian).

[2] Watkiss P. The Cost of Climate Change in Europe. In: Steininger K., König M., Bednar-Friedl B., Kranzl L., Loibl W., Prettenthaler F. (eds) Economic Evaluation of Climate Change Impacts. Springer Climate. Springer, Cham. 2015. DOI: 10.1007/978-3-319-12457-5_2

[3] Kovalenko P., Rokochinskiy A., Mazhayskiy Y., Volk P., Volk L., Chernikova O. Construction and agricultural drainage parameter optimization considering economic and environmental requirements. Engineering for Rural Development, Jelgava, 20.-22.05.2020. pp. 1009-1017. DOI: 10.22616/ERDev.2020.19.TF237 
[4] Rokochynskiy A., Volk P., Turcheniuk V., Tokar L., Volk L., Mazhayskiy Y., Chernikova O. The drainage module is an important factor in the design of drainage systems reconstruction and construction projects in the polesia region engineering for rural development. Engineering for Rural Development. Jelgava, 20.-22.05.2020. pp. 36-47. DOI: 10.22616/ERDev.2020.19.TF010.

[5] Hebbink A.J. Land drainage. In: Environmental Geology. Encyclopedia of Earth Science. Springer, Dordrecht. 1999. DOI: 10.1007/1-4020-4494-1_196

[6] Pasaribu, K.N., Lambert, L.H., Lambert, D.M. et al. Profitability of irrigating for corn, cotton, and soybeans under projected drought scenarios in the Southeastern United States. Irrig Sci 39, 2021, pp. 315-328. DOI: 10.1007/s00271-020-00707-x

[7] Łabędzki L., Kaca E., Brandyk A. Irrigation and Drainage in Polish Agriculture: State, Problems and Needs. In: Zeleňáková M., Kubiak-Wójcicka K., Negm A.M. (eds) Quality of Water Resources in Poland. Springer Water. Springer, Cham, 2021. DOI: 10.1007/978-3-030-64892-3_5

[8] Kamra S.K., Kumar S., Kumar N., Dagar J.C. Engineering and Biological Approaches for Drainage of Irrigated Lands. In: Dagar J., Yadav R., Sharma P. (eds) Research Developments in Saline Agriculture. Springer, Singapore, 2019. DOI: 10.1007/978-981-13-5832-6_18

[9] Seyedmohammadi, J., Esmaeelnejad, L. \& Ramezanpour, H. Land suitability assessment for optimum management of water consumption in precise agriculture. Model. Earth Syst. Environ. 2, 162, 2016. DOI: $10.1007 / \mathrm{s} 40808-016-0212-9$

[10] Rokochinskiy A., Frolenkova N., Turcheniuk V., Volk P., Prykhodko N., Tykhenko R., Openko I. The variability of natural and climatic conditions in investment projects in the field of nature management. Journal of Water and Land Development. No. 48 (I-III), 2021, pp. 48-54. DOI: 10.24425/jwld.2021.136145.

[11] Мажайский Ю.А., Рокочинский А.Н., Волчек А.А., Мешик О.П., Езнах Е. Природообустройство Полесья (Environmental management of Polesie). Ryazan: Meshcher.fVNIIIGiM them. A.N. Kostyakova, 2017, 902 p. (In Russian).

[12] Янголь А.М. Рекомендации по увлажнению осушаемых земель. К.: Урожай, 1965. 88 с. (In Ukrainian).

[13] Radchenko I. Ursovanie navrhovych parametrov regulacnej drenaze.-Agromelio-76, Karlovy Vary, 1986,d.2, pp. 102-108. (In Polish).

[14] Турбин В.Н. Двустороннее регулирование водного режима почв.-М.:Россельхозиздат, 1977, 72c. (In Russian).

[15] Лабренцис В.М. Исследования вопросов регулирования режима влажности почв дренажными системами двустороннего действия в условиях Латвийской ССР. Автореф.дис.соискание уч. степени канд.техн.наук. - Елгава,1974.-38. (In Russian). 